\title{
SUBJECTIVE WELL-BEING PADA MANTAN PASIEN SKIZOFRENIA
}

\section{SUBJECTIVE WELL-BEING IN EX-SCHIZOPRENIA PATIENTS}

\author{
Anis Mujaidha', Wanodya Kusumastuti ${ }^{2}$, Meriam Esterina ${ }^{3}$ \\ Program Studi Psikologi Universitas Muhammadiyah Purworejo \\ corresponding email: anismujaidha@gmail.com
}

\begin{abstract}
Becoming a former patient of schizophrenia requires a supportive adjustment process in his daily life. From early healing conditions to the recent conditions are certainly having fluctuant aspects of social, cognitive, and psychological aspects. The research is aimed to investigate the subjective well-being of former schizophrenic patients. The research method used was qualitative case studies. The study was using a qualitative approach with case-study methods. The number of respondents in this study is defined by a sampling technique. Data retrieval used semi-structured interviews.The analysis shows the two respondents have variative subjective well-being. The respondent AS, by under his living satisfaction over domains and positive feeling, dominates negative feeling more. Whereas respondent $Q$ showed that the satisfaction of his job is good enough. It is shown by the appeared positive feeling which is more dominant, meanwhile, the negative feeling only appears in certain conditions, such as when the respondent was tired or when he remembered and missed their closest people in his life.
\end{abstract}

Keywords: Subjective well-being, Former schizophrenic patient

\begin{abstract}
ABSTRAK
Menjadi seorang mantan pasien skizofrenia memerlukan proses penyesuaian yang mendukung dalam fungsi kehidupan sehari-hari. Kondisi awal sembuh hingga saat ini tentu mengalami fluktuatif berbagai aspek yaitu aspek sosial, aspek kognitif serta aspek psikologis. Penelitian ini bertujuan untuk melihat gambaran subjective well-being pada mantan pasien skizofrenia. Penelitian ini menggunakan pendekatan kualitatif dengan metode studi kasus. Responden pada penelitian ini berjumlah 2 responden yang ditentukan dengan teknik purposive sampling. Pengambilan data menggunakan wawancara semi terstruktur. Hasil analisis menunjukkan kedua responden memiliki subjective well-being yang bervariasi. Responden AS terlihat dari kepuasan hidupnya diseluruh domain dan afek positif lebih mendominasi afek negatifnya. Sedangkan untuk responden $T$ terlihat dari kepuasan pekerjaannya memiliki afek positif yang cukup baik serta memiliki kepuasan hidup sedangkan afek negatifnya hanya muncul pada saat kondisi tertentu misalnya ketika responden sedang lelah atau teringat dan merindukan orang terdekat.
\end{abstract}

Kata kunci: Subjective well-being, Mantan pasien skizofrenia

\section{PENDAHULUAN}

Sehat secara umum dapat dipahami sebagai kesejahteraan secara penuh. Menurut UU Kesehatan No. 36 tahun 2009 menyatakan bahwa sehat adalah suatu keadaan sehat 
secara fisik, mental, sosial. Ketiga bentuk kesehatan ini memiliki makna yang berbeda. Sehat secara fisik artinya terhindar dari penyakit fisik lainnya. Sehat secara sosial yaitu mampu berinteraksi dengan baik. Sedangkan sehat secara mental yaitu mampu mengelola emosi dan stres dengan baik (WHO, 2019).

Seseorang yang mentalnya sehat dapat menggunakan kemampuan atau potensi dalam dirinya secara maksimal. Hal ini berkaitan dengan kesehatan mental yang merupakan kondisi dari kesejahteraan yang disadari individu, yang terdapat kemampuan-kemampuan untuk mengelola stres, bekerja secara produktif, dan berperan dikomunitasnya (WHO, 2021). Salah satu jenis masalah kesehatan mental adalah gangguan jiwa. Gangguan jiwa merupakan suatu keadaan dimana individu mengalami kesulitan dengan persepsinya terhadap kehidupan, kesulitan dalam menjalin hubungan dengan orang lain, serta kesulitan dalam menentukan sikap dirinya sendiri (Aula, 2019).

Salah satu bentuk dari gangguan jiwa adalah skizofrenia. Skizofrenia merupakan gangguan kejiwaan kronis yang membuat pengidapnya sulit membedakan antara kenyataan dan khayalan. Gangguan skizofrenia ini dapat mempersulit orang yang melakukan pekerjaan atau belajar secara normal (World Health Organization, 2018). Skizofrenia merupakan gangguan mental kronis yang menyerang sekitar 20 juta orang diseluruh dunia (James et al., 2018), sedangkan di Indonesia jumlah penderita gangguan jiwa sekitar 450 juta jiwa termasuk skizofrenia (World Health Organization, 2017). Hasil analisis data dari Riset Kesehatan Dasar 2018 (Riskesdas) menunjukkan bahwa prevalensi skizofrenia di Indonesia sebanyak 7\% per 1000 rumah tangga. Hal ini menunjukkan bahwa dari 1000 rumah tangga, terdapat 70 rumah tangga yang mempunyai anggota dengan pengidap skizofrenia atau psikosis berat.

Diperoleh informasi dari portal resmi provinsi Jawa Tengah (Jatengprov.go.id, 2021) satu dari empat orang atau sekitar 25 persen warga Jawa Tengah mengalami gangguan jiwa ringan kategori gangguan jiwa berat rata-rata 1,7 per mil atau kurang lebih 12 ribu orang. Menurut data Dinas Kesehatan Kabupaten Purworejo tahun 2017 sampai bulan April 2017 menyebutkan bahwa jumlah pasien gangguan jiwa di Kabupaten Purworejo 2.769 yang mana dari jumlah tersebut sebanyak 720 pengidap gangguan skizofrenia. Data terbaru dari Dinas Sosial Kabupaten Purworejo (2020) tercatat masih banyak orang dengan gangguan jiwa di Kabupaten Purworejo. Dari 16 kecamatan di 
Kabupaten Purworejo, Kecamatan Bayan menempati urutan teratas dengan jumlah sekitar 384 ODGJ (orang dengan gangguan jiwa) yang tersebar di 26 Desa.

Sebagian masyarakat sudah mendapatkan penanganan di rumah sakit dan panti rehabilitasi lainnya di Purworejo. Salah satu panti rehabilitasi yang menerima pasien skizofrenia dalam tahap pemulihan adalah Tirtoo Jiwo. Peneliti melakukan wawancara terhadap salah satu pegawai di panti rehabilitasi Tirtoo Jiwo yaitu AS. AS merupakan seorang mantan pasien skizofrenia yang telah sembuh selama 11 tahun, ia bekerja sebagai administrasi serta memantau kondisi pasien gangguan jiwa lainnya. Kondisi AS saat ini sudah lepas obat dan dapat produktivitas bersama keluarganya.

Dalam hal ini ketika menjadi seorang mantan pasien skizofrenia memerlukan proses adaptasi yang kompleks. Proses kondisi awal sembuh hingga saat ini tentu mengalami fluktuatif berbagai aspek yaitu, aspek sosial, aspek kognitif serta aspek psikologis. Mantan pasien yang beradaptasi dengan kehidupan sehari-hari mulai dari pekerjaan, hubungan dengan orang lagi, serta tekanan-tekanan yang dialaminya apakah akan menganggu kebahagian subjektifnya. Sejalan dengan hal tersebut, Naughton dan Weafer (2014) melaporkan bahwa kesehatan mental yang berkaitan dengan kepuasan hidup yang buruk lebih lazim di temui pada penderita penyakit kronis sebesar enam kali lebih tinggi jika dibandingkan dengan orang dewasa tanpa penyakit.

Masyarakat yang tidak memahami tentang kondisi tersebut akan memberikan stigma negatif. Pandangan mayoritas masyarakat membuat enggan untuk berinteraksi dengan mantan pasien skizofrenia. Disatu sisi mantan pasien skizofrenia membutuhkan penerimaan lingkungan untuk mengurangi resiko kekambuhan. Pengalaman dari emosi yang menyakitkan terhadap mantan pasien skizofrenia seperti kecewa, kegagalan, maupun duka cita adalah bagian normal dari kehidupan, dan mampu mengatur emosiemosi negatif merupakan hal yang penting dalam kesejahteraan subjektifnya. Selanjutnya, Ariati (2010) menjelaskan bahwa individu yang memiliki tingkat kesejahteraan subjektif tinggi meski dalam keadaan penuh tekanan dapat melakukan adaptasi dan koping yang lebih efektif terhadap keadaan tersebut sehingga merasakan kehidupan yang lebih baik.

Namun kesejahteraan mantan pasien skizofrenia bisa terancam ketika emosiemosi negatif yang ekstrim atau berlangsung sangat lama mempengaruhi kemampuan seseorang untuk berfungsi dalam kehidupannya sehari-hari (Huppert, 2009). Dalam hal 
ini kebahagiaan merupakan sesuatu yang bersifat individual. Masing-masing orang memiliki cara pandangnya sendiri dalam melihat dan memaknai arti kebahagian. Melihat hal ini Diener menjelaskan kebahagian yang individual ini dengan konsepnya yang disebut subjective well-being.

Berdasarkan uraian di atas, peneliti tertarik untuk mengetahui lebih dalam tentang gambaran kesejahteraan subjektif atau subjective well-being pada mantan pasien skizofrenia.

\section{METODE PENELITIAN}

Penelitian ini menggunakan pendekatan kualitatif studi kasus yang bertujuan untuk mendeskripsikan hasil penelitian. Analisis penelitian kualitatif bersifat induktif dan hasil penelitiannya lebih menekankan bersifat induktif dan hasil penelitiannya lebih menekankan pada makna dari pada generalisasi (Sugiono, 2011). Penelitian ini menggunakan 2 responden dengan teknik sampling purposive sampling. Purposive sampling adalah teknik pengambilan sampel sumber data dengan pertimbangan tertentu dimana sampel merupakan responden yang diharapkan dengan memberikan data yang akurat, hal tersebut akan mempermudah penelitian pada responden yang diteliti (Sugiyono, 2010). Peneliti menggunakan wawancara observasi sebagai metode pengumpulan data. Teknik analisis data yang digunakan dalam penelitian ini adalah reduksi data, penyajian data, dan kesimpulan menurut Miles dan Hubbermen dalam Sugiyono (2014). Teknik verifikasi data dalam penelitian ini adalah triangulasi sumber. Triangulasi sumber untuk menguji kredibilitas data yang sudah dilakukan dengan cara mengecek data yang telah diperoleh melalui berbagai sumber (Sugiyono, 2011).

\section{HASIL PENELITIAN}

Berdasarkan penelitian yang telah dilakukan temuan individu kedua responden yaitu:

\section{Responden I (AS)}

Berdasarkan hasil wawancara yang dilakukan dengan responden AS, AS merupakan mantan pasien skizofrenia yang telah sembuh,AS terdiagnosa skizofrenia pada tahun 2006-2009 pada usia 40 tahun. Penyebabnya adalah masalah anak. AS tidak menceritakan dan terbuka dengan orang terdekat sehingga menyebabkan AS mengalami penarikan diri dari lingkungan sosial karena menjadi perbincangan warga sekitar dan 
sering menyendiri, lalu gejala positif muncul berupa halusinasi dan delusi. Setelah beberapa kali mendapatkan pengobatan baik non medis maupun medis AS kini kembali dengan kondisi yang normal.

Kesejahteraan subjektif meliputi evaluasi kognitif responden mengenai kepuasan kehidupannya secara keseluruhan. Evaluasi kognitif yang dilakukan oleh responden memunculkan penilaian seberapa puaskah kehidupannya yang selama ini mulai dari masa lalu hingga saat ini. AS responden pertama menunjukkan subjective well-being yang baik ditunjukkan dengan menerima masa lalu dan saat ini serta AS memiliki rencana pada masa depan. AS tidak terlalu memikirkan tanggapan negatif dari orang lain, ia hanya fokus untuk dirinya sendiri dan keluarga. Sehingga ia bekerja dengan semangat dan ulet.

AS memiliki hubungan yang baik dengan keluarganya, dari hubungan yangbaik tersebut AS mendapatkan motivasi serta dukungan yang sangat berarti. Car, Freedman, Comman, dan Schwarz (2014) mengatakan bahwa orang yang berbahagia adalah individu yang menikah, mempertahankan pernikahannya. Perasaan yang saling menjaga dan menguatakan satu sama lain merupakan bentuk kasih sayang AS.

AS memiliki regulasi emosi yang bagus ia bisa mengelola ketika sedang marah atau kecewa, tidak terlalu larut di dalam keadaan tersebut. Selalu berpikir positif dan mensyukuri segala bentuk pemberian tuhan. AS memiliki religiusitas yang bagus dengan mendekatkan dirinya terhadap tuhan dan mempasrahkan semua yang terjadi serta ia melakukan hobi atau kegiatan yang disukai seperti sepeda, bernyanyi atau mendengarkan musik, ketika sudah melakukan kegiatan tersebut ia tidak memikirkan masalahnya, karena menghasilkan ketenangan dan damai di dalam hatinya sehingga ia merasa bahagia.

\section{Responden II (T)}

Berdasarkan hasil wawancara yang dilakukan terhadap responden $\mathrm{T}, \mathrm{T}$ merupakan mantan pasien skizofrenia yang terdiagnosa pada usia 48 tahun yaitu tahun 2015. Penyebab T mengalami skizofrenia adalah memiliki masalah dengan tetangga terkait pompa air, $\mathrm{T}$ salah berucap kepada temannya lalu $\mathrm{T}$ dilaporkan dan dijauhi tetangganya, serta masalah pekerjaan. Penanganan yang diberikan terhadap T sangat cepat karena mengalami gangguan jiwa hanya 1 tahun saja. Setelah berobat dan rajin mengkonsumsi obat ia sudah dapat produktivitas seperti biasa, walaupun kondisi saat ini 
masih konsumsi obat dengan dosis rendah, tetapi psikiatri sudah menyatakan bahwa T sembuh.

Berdasarkan hasil penelitian subjective well-being $\mathrm{T}$ adalah sudah menerima semua jalan kehidupannya dimasa lalu, akan tetapi $\mathrm{T}$ belum memikirkan dan belum merencanakan, apa yang akan ia lakukan dimasa depan. T memiliki karakteristik kepribadian yang pendiam dan tak banyak bicara, ia tidak terlalu memikirkan perkataan negatif orang lain. Responden $\mathrm{T}$ dalam kemampuan menyelesaikan masalah didalam pekerjaannya memiliki kapasitas yang bagus hal ini berdasarkan wawancara dengan SO dan $\mathrm{T}$ juga diberikan tanggung jawab dalam mengelola keuangan di panti, responden $\mathrm{T}$ juga tidak pernah terlibat konflik dengan pegawai lainnya, dalam hal ini $\mathrm{T}$ memiliki perasaan sedih karena harus berjauhan dengan anak dan istri, tetapi ia memiliki regulasi yang baik. T memiliki religiusitas yang bagus, dengan perilaku mendekatkan diri kepada tuhan serta beribadah dengan rajin.

Kondisi T saat ini harus berjauhan dengan keluarganya terutama anak dan istri. T ada perasaan sedih jika tidak bertemu dengan keluarganya, akan tetapi ketika $\mathrm{T}$ rindu mereka berkomunikasi melalui telephone. Hubungan $\mathrm{T}$ dengan keluarganya tidak ada permasalahan, bentuk kasih dan cinta yang $\mathrm{T}$ berikan terhadap keluarga adalah dengan memberikan transferan uang dan bercerita terkait dengan kegiatan di Panti. Karena T bekerja dan bertempat tinggal dip anti tersebut.

Diener (2012) menjelaskan bahwa kemampuan seseorang untuk melakukan intropeksi dan mengambil hikmah dari berbagai peristiwa yang terjadi memiliki peranan penting terhadap kebahagiaan seseorang. Sejalan dengan hal tersebut, menurut King Laura (2013) menyatakan bahwa individu yang melakukan intropeksi diri cenderung menjadi pribadi yang lebih dewasa dan dapat menambah potensi kebahagiaan mereka. Selain itu Diener, Lucas, dan Oishi (2002) menyatakan bahwa individu yang mengevaluasi dirinya secara positif akan memiliki kontrol yang baik terhadap kehidupannya sehingga memiliki impian dan harapan. Hal ini sesuai dengan apa yang telah dilakukan responden mengenai kehidupannya selama ini, responden mampu mengambil hikmah dan mampu melakukan intropeksi sehingga ia dapat menerima kehidupannya saat ini dengan hati lapang dan tetap merasakan kebahagiaan. 


\section{KESIMPULAN}

Kesejahteraan yang dimiliki oleh kedua responden dari kepuasan hidup dengan masa lalu dan pandangan akan kepuasan dalam kehidupan saat ini. Kepuasan hidup dengan masa lalu kedua responden ditandai dengan adanya pengalaman sebelumnya sebagai mantan pasien skizofrenia keduanya sudah menerima masa lalu dengan baik sehingga memberikan kesan bagi responden. Kedua responden juga memiliki kepuasan akan kehidupan saat ini yang dijalaninnya sebagai mantan pasien skizofrenia, hal ini ditunjukkan dengan kedua responden yang bersyukur akan kondisi dijalaninya saat ini serta memiliki semangat dalam pekerjaanya.

Kesejahteraan subjektif yang dimiliki oleh kedua subjek dalam penelitian ini dipengaruhi oleh beberapa faktor, untuk responden AS peristiwa hidup yang menyenangkan, kepuasan kerja, rekreasi dalam bentuk olahraga bersepeda dan juga ciri kepribadian subjek yang sekarang terbuka. Sedangkan T dipengaruhi oleh pekerjaan, kegiatan sederhana di panti, serta responden $\mathrm{T}$ terbuka dengan keluarganya.

\section{DAFTAR PUSTAKA}

Carr, D., Freedman, V. A., Cornman, J. C., \& Schwarz, N. (2014). Happy marriage, happy life? marital quality and subjective well-being in later life. Journal of Marriage and Family, 76(5), 930-948. doi:10.1111/jomf.12133Diener, Ed., Lucas, R. E., \& Oishi, S. (2002). Subjective well being: The science of happiness and life satisfaction. In Handbook of Positive Psychology (C. R. Snyder, Shane J. Lopes, Ed.). United Kingdom: Oxford University Press.

Eddy, F. N. E., Septa, T., \& Angraini, D. I. (2017). Diagnosis dan Tatalaksana Skizofrenia Hebrefenik Putus Obat dengan Logorrhea. In Jurnal Medula (Vol. 7, Issue 3) www.ttps://juke.kedokteran.unila.ac.id/index.php/medula/article/view/816.co $\underline{\mathrm{m}}$

Eka, Aulia., \& Rahmasari, Diana. (2019). Kesejahteraan Subjektif pada Laki-laki Dewasa Penderita Leukimea. Jurnal Psikologi, Fakultas Ilmu Pendidikan, UNESA. Huppert, F. A (2009). Psychologycal Well-Being: evidence regarding its causes and consequences. Applied psychology: health and well-being. 1(2), 137-164.

https://doi.org/10.1111/j.1758-0854.2009.01008.x

King, Laura A. (2013). Psikologi umum: Sebuah pandangan apresiatif. Jakarta: Salemba Humanika.

Pietrini, F., Albert, U. Ballerini, A. (2019). The modern perspective for long acting injectables antipsychotic in the patient-centered care of schizophrenia. $\begin{array}{llll}\text { Neuropsychiatric Disease and Treatment, } & 15\end{array}$ https://doi.org/10.2147/NDT.S199048

Prognosis Schizophrenia - Alomedika. (n.d.). Retrieved November 9, 2020, from https://www.alomedika.com/penyakit/psikiatri/schizophrenia/prognosis.com 
Poerwandi, K. (1998). Pendekatan Kualitatif dalam Penelitian Psikologi. Jakarta: Universitas Indonesia

Riskesdas. (2018). Kementerian Kesehatan RI. Badan penelitian dan pengembangan kesehatan. https://kesmas.kemkes.go.id/assets/upload/di

Stuart \& Laraia. (2005) Buku Saku Keperawatan Jiwa. Jakarta: EGC

Stuart, G.W. (2013). Buku Saku Keperawatan Jiwa. Edisi 5. Jakarta. EGC.

Scott, J., \& Connell, M. (2017). Halluconations in adolescents an risk of mental disorder and psychosocial impairment in adulthood: a birth cohor study. Schizophrenia Bulletin, 43(1), 58.

Sugiyono, (2010). Metode Penelitian Pendekatan Kuantitatif, Kualitatif, dan R\&D. Penerbit Alfabeta. Bandung. 2016

WHO. (2019). Schizopherina. Retrieved from. https://www.who.int/news-room/fact

WHO. (2001). Basic Documents. 43 ${ }^{\text {rd }}$ Edition. Geneva: World Health Organization vocational high school students. International Journal of Evaluation and Research in Education, 8(2), 237-242. 